\title{
IMPLICATURE IN SAIKIRAN'S STAND UP COMEDY SCRIPT DARK SKIN AND GETTING MARRIED
}

\author{
Siti Nurhaliza, Zulfan Sahri \\ Department of English, Faculty of Literature, \\ Universitas Islam Sumatera Utara, Medan 20217, Indonesia; \\ e-mail: nurhalizza9@gmail.com
}

Received: 2021-10-02

Accepted: 2021-11-09

\begin{abstract}
This research focuses on implicature in Saikiran's Stand Up Comedy Script Dark Skin and Getting Married, and the analysis is done to all types of implicature found in the script. The make up of this research strongly refers to the use of descriptive qualitative method to process the data, which are originally taken from the script. The analysis reveals two types of implicature: cconventional implicatures and conversational implicatures. Conventional implicature is associated with the general meaning and also related to specific words (but, and, even); meanwhile, conversational implicature verifies two types: generalized conversational implicature and particularized conversational implicature. There are 13 data referring to cconventional implicatures and 4 data to conversational implicatures (2 data generalized conversational implicatures and 2 data particularized conversational implicatures). The results of this research indicate that Saikiran uses those implicatures when he wants the audience to understand about his life condition in funny ways, and the audience will possibly find it difficult to understand if they do not know his utterances in the contexts.
\end{abstract}

Keywords: Stand Up Comedy, Script, Conventional implicature, Conversational Implicature

\section{Introduction}

Comedy is a kind of humor as a way to make the audience laugh and comfort for our daily activity, and it often becomes different from other stage performances because it has a specific goal. Comedy is intended to make the situation funny; it creates amusement or the ability to enjoy funny situations and to laugh at things. Wijana (2004: 37 ) describes that comedy or humor can be arranged as a means of communication in the form of stimulation which tends to spontaneously cause smiles and laughter of the audience. Comedy also has an important role in human life as an entertainment to release people's psychological tensions and burdens, but also as a means of social criticism against deviations that occur in society. Through comedy, social criticism can be expressed in harmonious language, and has a relaxed and intriguing impression for the audience.

Nowadays, stand up comedy becomes popular in Indonesia as the new way to entertain people. It is a kind of humor which can be performed individually or in a group. Yamazaki (2010: 67) says, "stand-up comedy is one of the common styles of 
comedy performed on the stage where a comedian talks directly to the audience by cracking jokes and telling funny stories." Moreover, stand up comedy is a kind of comedy which is monologue in which the audience will listen to what comics want to share. What makes stand up comedy different from other comedies is that the material or the topic in stand up comedy is truly exist in our life. The stand up comedians, or are usually called as comics always do some observation to support their opinion. Thus, it becomes a new thing in the kind of comedies. In stand up comedy, the things like aspiration, restlessness, opinion are freely to be shared. Furthermore, the comics intentionally share their restlessness when they are performing but they share it through funny ways. Thus, the comics always share their aspiration and restlessness implicitly.

Through this Stand Up Comedy Script Dark Skin and Getting Married, the comic, Saikiran shares about his life. He does not only focus on entertaining the audience, but also he wants to share about some issues which relates to his life and audience's. However, the audience will not only enjoy his performance by laughing, but they will get information by understanding the intended meaning from Saikiran's utterances.

In stand up comedy, language as a media of communication uses certain type of pronunciation that is inconsistent with utterance. Therefore, the proper media to discuss this matter is by introducing pragmatics. Pragmatics is a branch of linguistics that studies discourse and studies meaning. Pragmatics examines four things, namely deixis, presuppositions, speech acts, and implicatures - among these aspects, implicature is taken as a research study. Implicature is speech that implies something different from what is actually spoken. The term of implicature is used by Grice (1975: 44) to account for what a speaker can imply, suggest, or mean, as distinct from what the speaker literally says. For example: The ceremony is so long; it could go on forever. From this example, readers may understand that the statement shows how boring he/she is even he/she does not say it explicitly. Implicature can show what is intended to convey. Then, hearers may imply further information from what the speaker actually says.

With the above points in mind, the utterance of English language in youtube stand-up comedy contains the implicature. The variants of its utterance make it plausible to bring the implicature into a research since it grows an interest to other people about what they have said or what massage they need to convey. For this reason, the research finally pertains to implicature from Saikiran's Stand Up Comedy Dark Skin and Getting Merried.

\section{Literature Review}

One of the most important aspects of pragmatics, apart from deixis, presupposition, speech acts, etc. is implicature, and it is firstly introduced by Grice (1975: 44) to encounter the issue that there is meaning beyond what is merely conveyed in communication. Thus, to understand a speaker's message, a hearer should be able to guess the intended meaning because sometimes the speaker delivers information more than what she or he is really said. The speaker may deliver the message both explicitly and implicitly.

Implicature indicates the act of meaning, implying, or suggesting one thing by saying something else. So, what a speaker means is different from what the sentence used by the speaker means; it can be viewed as an implicature.

Grice (1989: 31) divides implicature into conventional implicature and conversational implicature. He indicates that conventional implicature is identified by 
the conventional meaning of the words used. They are simply attached by convention to particular lexical items or expression. In general, everyone has known and understood the meaning of a case. Understanding this conventionally supposes the listener or reader to have general knowledge. Grice (1989: 31) verifies the relation of the basic statement in an utterance which can be used with conjunction such as even, and, moreover, but, therefore, on the other hand, or yet. For example, Jack is rich but unhappy. (The utterance which implies richness and unhappiness are not compatible, but they can be combined well by the use of the word but which always creates the implicature of a sense of contrast. So Jack is rich but unhappy conveys the meaning of Suprisingly, Jack is unhappy in spite of being rich).

Another example for this is that He met a lady. (The word lady contains implicature which produces specific information such as hair, lip, eyes and nose. It does not mean that he met a lady who has nose, hair, eyes and nose, but it is just related with the particular lexical item referring to conventional implicature.

Furthermore, conversational implicature, according to Grice (1975: 45), occurs in a conversation when the speaker implicates something in his/her utterance by observing the conversational maxims: maxim of quantity (be as informative as required), maxim of quality (be true), maxim of relevance (be relevant), and maxim of manner (be perspicuous), or at least the cooperative principle. Cooperative principle, as the basic rule of Grice's conversational implicature, says that participants of a conversation have to make their conversational contribution as required. It means that the speaker is expected to contribute what is required by the purpose of the conversation. In other words, the cooperative principle and its maxims are the indicators of conversational implicature.

Grice (1989: 31) divides conversational implicature into two types: generalized conversational implicature and particularized conversational implicature. Generalized conversational implicature appears without having any specific context, and it is made without showing any reference to a special context. For example:

A: I wish you sell your house and car.

B: I sell my car.

Here, the speaker B does not mean to sell the house, as the speaker A expects in the utterance.

Meanwhile, particularized conversational implicature needs a certain context (context-bound). Implicature of this type is made particular for utterances that are relevant only with respect to the particular topic or issue at hand. For example:

A: Now, John looks happy after his marriage.

B: That's fine. He has an Asian wife.

In this context, it shows that the speaker A confirms that John has happiness after he has got marriage. But in particular context, the hearer $\mathrm{B}$ answers by saying He has an Asian wife. The speaker A needs to interpret what the hearer B answers to get meaning of his friend's particular utterance by identifying that an Asian wife is a dedicated and workaholic wife.

The above description indicates that particularized conversational implicature may convey its meaning out part of the utterance so that hearer must have knowledge more to understand what speaker means. In other words, particularized conversational implicature is the inferences of hearer which only can work out, or be interpreted while drawing totally on the specific context of the utterance. Implicature and its types are 
able to be used by speakers in order to create particularized context of utterances based on situations and conditions.

Context is one of the factors that gives an effect to people how they use the language. Yule (1996: 21) states that context simply means the physical environment in which a word is used. The importance of taking of context into account is also well expressed by Hymes (in Brown and Yule, 1983: 37) who views the role of the context in interpretation as, on the other hand, limiting the range of possible interpretation and, contrarily, as supporting the intended interpretation.

According to Grundy (2000: 72), context helps us to determine what is conveyed implicitly but not explicitly stated by the speaker. He also adds that context is not treated as given common ground, but rather as a set of more or less accessible items of information which are stored in shorterm and encyclopedic memories or manifest in the physical environment. Macro and micro contexts are often drawn in the conversation analytic. Macro contexts are said to be 'distal' in the sense that they exist outside the talk exchange. In contrast, micro contexts are created within the micro domain of the talk exchange. So, whether talk is determined or constrained by distal context with context seen as presumptive or whether in fact it is talk which creates context (Grundy, 2000: 195).

A context can support a range of meanings. When a form is used in a context, it eliminates the meaning possible to that context other than those the form can signal: the context eliminates from consideration the meanings possible to the form other than those the context can support.

\section{Research Method}

As this paper is concerned with implicature, a design to do an analysis is strongly required by following what Creswell (2009: 3) describes that in the design, plans and the procedures for research involve the detailed methods of data collection and analysis become preliminary aspects of research. This paper is arranged to discuss about implicature in Saikiran's Stand Up Comedy Script Dark Skin and Getting Married, and uses the theory of implicature proposed by Grice (1975: 44) to find the types, and to describe meanings of conventional implicature and conversational implicature uttered by Saikiran in written form or script. To do the analysis, descriptive research method is the most appropriate method to be used. It follows what Bogdan and Taylor (2008: 4) says that research that produces descriptive data consists of written or spoken words from people. In this respect, the descriptive method is solely used to describe the data that are taken from written form of Comedy Script.

Searching for the data related to implicatures on the script and making a note on the selected data are specifically conducted to gain information about conventional implicature and cconversational implicature. Then, collecting information from some references that support the subject matters of the discussion is also respectively prepared for completing the procedures. The analysis is then made by taking the utterances which contain all types of the implicatures found in the Comedy Script i.e conventional implicature and conversational implicature covering generalized conversational implicature and particularized conversational implicature. At last, the meaning implied in each type of the implicature is made up under description. 


\section{Discussion}

All of the types of implicature: conventional implicature and conversational implicature; generalized conversational implicature and particularized conversational implicature in Saikiran 's Stand-Up Comedy become the variables of analysis which are primarily based on Grice's theory of implicature, as described in the following subsections.

\subsection{Conventional Implicature}

Conventional implicature is associated with the general meaning and also related to specific words (but, and, even) and those words may carry additional conveyed meaning when they are used. In addition, implicature of this type is not based on pragmatic principles, or it does not need special context for interpretation. As described in the following from 1 to 13 , Saikiran utters more on conventional implicatures in the Stand Up Comedy that imply additional conveyed meanings.

[01] Most girls who see me for the first time don't like me

If only they spend some time with me

and get to know me better

They start truly hate me

even when I am silently walking on the road

(Saikiran, 2018: 1)

The utterance is related to specific words even that means contrary to expectation when it is used. The utterance in even when I am silently walking on the road implies that although he does not do anything or disturb the women only seeing his appearance will attract their attention and guess him as a bad guy. The utterances imply that many women do not like men who have dark skin. There is additional conveyed meaning shown here. So, the utterances are suitable to be categorized as conventional implicatures.

[02] Any woman coming in the opposite direction

Instinctively crosses to the other side of the road

and nowadays with all this news about violence against women.

The women see me

They start covering themselves with their saree pallus like this

One day I saw a girl do it and I just lost it

(Saikiran, 2018: 1)

The utterance in They start covering themselves with their saree pallus like this implies that Indian women have a traditional fabric saree pallus which is always worn by them on left shoulder. The utterances imply that the women try to avoid and hide their face by using saree pallus when they suddenly see Saikiran on the road because he looks like a person who want to do criminal to woman as in the news. Then, and here is used to add meaning in the context, so the utterances are classified into conventional implicatures.

Like when I was born in the hospital

looking at me their first reaction was AIYYO

They said it so loudly

(Saikiran, 2018: 1) 
The utterance $A I Y Y O$ implies that someone feels sorry for something happens. That utterance is a common expression in India to reveal distress. So, the utterances imply that Saikiran was born dark, and the doctor and nurse are shocked of seeing him for the first time and his family feels disappointed because their efforts are useless to make him fairer. The utterance has a general meaning in Indian language, and is classified into a conventional implicature.

[04]
My mom made it her mission in life
to make me fairer
She had a poster of Michael Jackson in the kitchen
If his mom can do it, I can do it

(Saikiran, 2018: 2)

The utterance She had a poster of Michael Jackson in the kitchen implies that Michael Jackson as the famous singer in the world which has fair and handsome face. So, the utterances imply that when his mother was being pregnant, she believes that if she sees Michael Jackson's poster every time, she will make her baby (Saikiran) like him. The utterances are categorized into conventional implicatures.

[05]
That's why South India are obsessed
with eating everything in white...
Rice with Curd, Appam with Stew
Idli with Coconut Chutney
doesn't make a difference
No mater the colour of what you eat
The result is still brown

(Saikiran, 2018: 2)

The utterance The result is still brown implies that whatever you do, it will affect nothing at all. The utterance is general in society. So, the utterances imply that Indian people usually eat white food to make their skin fairer but the result is useless because medical sciences have proven that the colour of skin will not change only by eating something white. The utterances are classified into conventional implicatures.

[06] Forget South Indian fair

Forget North Indian fair

Imagine an Afghanistani Albino

That's how fair she was

and they both got married

(Saikiran, 2018: 2)

The utterance Albino implies that people who are born without usual pigment. So, they look very pale skin, hair, and eyes. The utterances imply that Saikiran gives the example to audience which means how nice it would be if he had white skin like them. The additional conveyed meaning shown here is and. Thus, the utterances are categorized as conventional implicatures.

[07]

Because my grandfather was dark and rich.

My grandmother was fair and poor

now I am dark and poor

(Saikiran, 2018: 2) 
The utterance now I am dark and poor implies that he gets bad condition from the descendant both his grandfather and grandmother who have the lucky one. The utterances imply that Saikiran feels sad because he is dark skin and not rich. The and here is an additional conveyed meaning. Therefore, the utterances are classified as conventional implicatures.

[08]
These fair skinned morons think that
if a cow stays in the sun for too long
It becomes a buffalo
but, forget animals
even gods cannot escape this discrimination in our country

(Saikiran, 2018: 3)

The utterances imply that many words from white people demeaning blacks and this is common and inevitable in his country. There are additional conveyed meaning shown here i.e. even and but that indicate the meaning of contrary to expectation when it is used. In this respect, the utterances are normally referred to conventional implicatures.

[09]
So, in this country to whitewash brown skin
you need black money

(Saikiran, 2018: 3)

The utterances are included as conventional implicatures. The utterance black money means tax has not been paid to the government. The comic implies that in India, to make skin fairer must spend expensive maintenance by using money which they have not paid to the government as tax and the deed is illegal. It is because their salary will not be enough to do it.

[10]
My face is red with anger
but you can't notice it because of my skin colour
(Saikiran, 2018: 3)

The comic implies that when he looks very angry, it will not be known by people because of his dark skin which has covered the expression of anger. The word but creates sense of contrast as an additional conveyed meaning. So, the utterances are categorized as conventional implicatures.

\author{
NRis take away the top 20 export quality girls \\ The next 20 go to the two eyes of India IITs and IIMs \\ Men like me don't stand a chance \\ so clearly wrote in my profile \\ I may not bea NRI or an IITian but I am healthy \\ I am a vegetarian. I do not smoke or drink. \\ (Saikiran, 2018: 4)
}

The utterance NRI or an IITian implies that an Indian citizen who stays outside India for the purpose of employment or education. The utterances imply that there is no woman who wants to accept him as a partner because he comes from an unemployment and not a highly educated person although he is not like them, but he does not do anything bad. Nevertheless, the utterances are appropriately categorized as conventional implicatures. 
[12] I thought many women will be impressed by someone like that and I got five respons not from women but from people requesting blood and organ donation It was a bit painful but I took the money (Saikiran, 2018: 4)

The utterance is related to specific words but means contrast to the condition. The utterance but from people requesting blood and organ donation implies that he is on the stage at event in order to look for a fiancée to be married but women are not interested of him. Many people think that he wants to donate his organ. The utterances imply that Saikiran feels disappointed. Finally he does it and gets money from donation. The utterances are categorized as conventional implicatures with additional conveyed meanings.

\author{
They gave me a free upgrade \\ to the fresh faces section \\ of second shaadi.com \\ and there on this website I saw all these familiar girls \\ who five years ago rejected me \\ got married had kids got divorced \\ and again on this website again rejecting me \\ Déjà vu \\ They say I am incompatible with their kids \\ If you agreed five years ago that would have been my kid \\ (Saikiran, 2018: 4)
}

The utterance Déjà vu implies that the feeling has lived through the presents situation before. The utterances imply that Saikiran tries again in the same website to look for a fiancee but it happens again; no women are interested in him although the women are widow. The event is same as five years ago when he tried it for the first time and it repeats to himself. It seems that an additional conveyed meaning and is found here, and therefore, the utterances are categorized as conventional implicatures.

\title{
4.2 Conversational Implicature
}

Conversational implicature is divided into two types namely, generalized conversational implicature and particularized conversational implicature. The utterances containing conversational implicatures are four; two generalized conversational implicatures and two particularized conversational implicatures.

\subsubsection{Generalized Conversational Implicature}

Generalized conversational implicature happens when the hearer has no intention to have a special knowledge of the context to estimate the additional conveyed meaning. With this characteristic, there are only two generalized conversational implicatures in Stand Up Comedy, as verified in the following: 
The utterances belong to generalized conversational implicatures. When the comic implied the utterances, the audience can understand the comic's intended meaning without having any background knowledge of context. There is a conversation between Saikiran and his mother in She says "I don't want to be a good mother or a great mother make me grand mother". The utterances imply that Saikiran praises his mother in front of people but his mother does not need it. She just wants Saikiran to get married as soon as possible and give her a grandchild. So, without a special knowledge, the audience can understand what the comic's intent.

[2]
Hey! What are you doing?
Do I look like a molester?
She said no no no
I thought you are a chain snatcher
(Saikiran, 2018: 1)

The utterances are categorized as generalized conversational implicatures. There is a conversation between Saikiran and a woman in She said no no no..I thought you are a chain snatcher. The utterances imply that the comic feels uncomfortable with the way that woman looks at him as if he is a bad guy. In the context, the woman is afraid of Saikiran's style which looks like a person who wants to steal something from the woman. So, the audience can be easy to understand the utterances because the utterances do not need a special knowledge to explain about the context.

\subsubsection{Particularized Conversational Implicature}

Particularized conversational implicature is a conversational implicature which is in contrast with the generalized conversational implicature. This implicature happens when the comic is saying something and implicitly the audience are giving the response. So, the audience must be able to understand the comis's utterances based on the context. Based on this characteristic, there are two particularized conversational implicatures to be discussed as indicated in the following:

[3] Like.. I am a fully grown adult today but My mom doesn't let me touch coffee or tea Saying drinking them will make me darker Boost and Bournvita also banned (Saikiran, 2018: 2)

The utterances cannot be understood well by the audience if the audience does not know the context. The conversation in Saying drinking them will make me darker implies that the particular context is some Indian people believe that the colour of food or drink will affect to your colour skin. Saikiran's mother tries hard to make him fairer when he was kid until adult. So, she forbids him to drink coffee or tea and Boost and Bournvita (kind of chocolate drink) because the colour is dark. For this reason, the utterances are categorized as particularized conversational implicatures.

Oh. They make so much fun on me

ArRey, Saikiran you are such a lucky guy

because you are dark

Unlike us.. you can go out in the sun whenever you want

as if my skin doesn't burn

This is melanin not teflon

(Saikiran, 2018: 2) 
Here, the audience must recognize the background of knowledge of the utterance. What Saikiran says in This is melanin not teflon has a particular context which must have a special knowledge to understand the utterances. Melanin is a skin pigment in the body. Meanwhile, teflon is synthetic chemical made from carbon and fluorine atoms. The utterances imply that there is no effect if you have dark skin, you will not be burned by the sun. Saikiran gives an example that we all as human have same natural pigment skin or melanin. If it is stricken by the sun directly, it will affect to the skin not like a teflon as cooked equipment which can withstand from the sun. So, the utterances imply that the comic shares her feeling of anger because of his cousin's saying. The utterances are categorized into the type of particularized conversational implicatures.

\section{Conclusion}

The analysis indicates that there are two types of implicature in the Stand Up Comedy: conventional implicature and conversational implicature. It verifies that conventional implicature in Saikiran's utterances are more general in nature, and it can be said that the audience have already known the meanings of many certain things expressed in it. Specific words as and, but, even that may provide meanings in his utterances can be easily recognized because of some additional meanings that are distinctly acquired; meanwhile, in conversational implicature, Saikiran shows the two types of utterances i.e generalized conversational implicature and particularized conversational implicature. In generalized conversational implicature, Saikiran talks to his mother and her mother's reply is different from what he says to her; however, the audience may catch and understand directly what her mother means to him. Besides, particularized conversational implicature indicates that their conversations between Saikiran and his cousin have a completely different meaning from what is said, so the audience should have special knowledge to understand the utterance.

\section{References}

Bogdan dan Taylor. (2008). Prosedur Penelitian. Dalam Moleong, Pendekatan Kualitatif. Jakarta: Rineka Cipta.

Brown, G., \& Yule G. (1983). Discourse Analysis. Cambridge: Cambridge University Press.

Creswell, J.W. (2009). Qualitative Inquiry and Research Design - Second Edition: Choosing among Five Approaches. California: Sage Publications, Inc.

Grice, Herbert Paul. (1975). Logic and Conversation. Cambridge, MA: Harvard University Press.

Grice, H.P. (1989). Studies in the Way of Words. Massachussetts: Harvard University Press.

Grundy, P. (2000). Pragmatics: An Introduction. London: Arnold.

Saikiran, (2019). Stand Up Comedy. Retrived from https://youtu.be/aTUiGWJinX0.

Wijana, I Dewa Putu. (2004). Kartun. Yogyakarta: Ombak.

Yamazaki. (2010). Conversational Implicature in Stand Up Comedies: Published Journal.

Yule, George. (1996). Pragmatics. New York: Oxford University Press 